\title{
FEMINISME KISAH MARYAM DALAM AL-QUR'ÂN DAN REKONSTRUKSI PEMAHAMAN GENDER PERSPEKTIF PRAGMATIK
}

\author{
Fathurrosyid \\ Institut Ilmu Keislaman Annuqayah Guluk-guluk Madura, Indonesia \\ E-mail: fathurrosyid090381@gmail.com
}

\begin{abstract}
This article discusses the story of Maryam in the Qur'ân with a pragmatic approach. This is because Maryam is textually a phenomenal figure, she even overcomes the social status of women such as 'Âishah and Fâtimah, so the name is documented in a special chapter popularly known as Surat Maryam. The article concludes that the construction of the theory of pragmatics against the Qur'ân is a discipline that examines the Qur'ân from the perspective of the relationship between linguistic context that is both dyadic and non-linguistic context that is triadic. The form of feminism is the story of Mary in the perspective of speech acts and implicatures in pragmatic approach of the Qur'ân that includes access to voice disappointment and resistance against misogynistic traditions contained in Q.S. Âli 'Imrân [03]: 36, gets access to educational rights contained in Q.S. Âli 'Imrân [03]: 37, access to implement spiritual teachings in public areas in Q.S. Âli 'Imrân [03]: 43, access to performs an injunction against the practice of sexual harassment in Q.S. Maryam [19]: 18 and a mother's responsibility to provide security and comfort for the baby, so that the baby did not die of starvation due to malnutrition he suffered.
\end{abstract}

Keywords: Pragmatic approach; the story of Maryam; feminism.

\section{Pendahuluan}

Kitab suci al-Qur'ân merupakan firman Allâh yang menggunakan beberapa variasi gaya bahasa (asâlîb muta'addidah) dalam menyampaikan pesan-pesannya, baik melalui pola naratif (al-bayân), argumentatif (al-burbân), diaologis-interaktif (al-takbâtub), dan kisah-kisah (al-qasass). ${ }^{1}$

1 Yûsuf al-Hâj Aḥmad, Mawsî́at al-Ijâaz al-Tlmî (Damaskus: Maktabah Dâr Ibn Hajar, 1424), 16. 
Artinya, firman Allah, selain memuat ideal type (berisi tentang konsep), juga didominasi oleh arche type (berisi tentang data historis). ${ }^{2}$ Pilihan penggunaan arche type karena lebih menghujam pada memory file dari pada ideal type. Adapun salah-satu data historis yang menarik untuk dikaji dalam konteks ini adalah kisah Maryam.

Beberapa alasan pentingnya menganalisis kisah Maryam adalah: pertama, secara tekstual, al-Qur'ân mendeklarasikan sosok Maryam adalah publik figur fenomenal, suci, dan terhormat, bahkan mengalahkan superioritas perempuan lainnya. Superioritas tersebut menjadikan Fakhr al-Dîn al-Râzî menempatkan posisi Maryam melebihi superioritas perempuan lain, semisal Siti Fatimah dan Siti Aisyah. ${ }^{3}$ Indikasi salah-satunya disebabkan al-Qur'ân tidak pernah menyebutkan nama seorang aktor di kalangan perempuan secara eksplisit, kecuali nama Maryam, bahkan kebesaran namanya diabadikan dalam satu surat khusus, yaitu berlabel Surat Maryam.

Kedua, kisah Maryam adalah kisah yang kaya dengan nuansa konteks, sehingga implikasinya terdapat susunan bentuk gramtikal yang berbeda sekalipun tema yanga diangkat sama. Fenomena ini misalnya tampak dalam penggunaan kalimat fîhâ yang berbentuk feminin (mu'annath) dalam Q.S. al-Anbiyâ' [21]: 91; sementara penggunaan kalimat fíh yang berbentuk maskulin (mudhakkar) terdapat dalam Q.S. al-Tahrîm [66]: 12. Selain itu, penyebutan nama Maryam secara jelas dan tegas terdapat dalam Q.S. al-Tahrîm [66]: 12, sementara kisah yang terdapat dalam Q.S. al-Anbiyâ' [21]: 91 penyebutan namanya justru dihilangkan.

Fenomena perbedaan susunan gramatikal tersebut tentu memiliki banyak pesan-pesan terdalam (meaning-ful sense) yang perlu diungkap secara akurat dan objektif. Hanya saja, analisis yang berhenti hanya pada konteks linguistik dan struktur gramatikal tidak akan cukup memadai untuk mengejar kebenaran hakiki (maqâsìi asâsîyah). Analisis pemahaman terhadap suatu teks semestinya dilanjutkan pada penyingkapan makna yang terdiamkan (al-maskut 'anb), yaitu makna yang tidak tercakup secara verbatim di dalam aksara sebuah teks. Pencapaian terhadap makna-makna itu tidak akan memadai jika hanya mengandalkan pada analisa struktur kalimatnya saja, tetap perlu

\footnotetext{
${ }^{2}$ Kuntowijoyo, Islam sebagai Ilmu Epistemologi, Metodologi, dan Etika (Jakarta: Teraju, 2004), 14-15.

${ }^{3}$ Fakhr al-Dîn al-Râzî, Mafâtîh al-Ghayb, Vol. 8 (Beirut: Dâr al-Kutub al-'Ilmîyah, 2000), 39.
} 
dilanjutkan pada analisa kelas, struktur sosial dan budaya yang melingkupi sejarah kehadiran teks itu sendiri. ${ }^{4}$

Dengan demikian, piranti pembacaan dan pemahaman terhadap kisah Maryam harus didasarkan pada konteks kebahasaan yangdalam kajian ilmu linguistik-disebut pragmatik. Sebab kehadiran metode pragmatik merupakan kajian bahasa yang membahas relasi bahasa dengan konteks kebahasaan yang menjadi dasar dan penentu objektif terhadap suatu penafsiran. ${ }^{5}$ Artinya, posisi pragmatik sendiri merupakan disiplin keilmuan yang tidak hanya berhubungan dengan aspek-aspek informasi dalam bentuk gramatikalnya saja, tetapi juga muncul secara alamiah pada makna-makna yang dikodekan secara konvensional dengan konteksnya. ${ }^{6}$

Berangkat dari fenomena di atas, maka artikel ini hendak mengungkap dua hal: Pertama, apa yang dimaksud pragmatika alQur'ân? Kedua, bagaimana bentuk feminisme kisah Maryam perspektif pragmatik? Adapun tujuan kedua pertanyaan tersebut, selain untuk memahami konsep pragmtika al-Qur'ân, juga untuk mengungkap bentuk feminisme kisah Maryam dalam teori tindak tutur dan implikatur perspektif pragmatik.

\section{Pragmatika al-Qur’ân: Model Pemahaman Berbasis Konteks}

Kalimat "pragmatika al-Qur'ân" merupakan kata majemuk yang berasal dari kata pragmatik dan al-Qur'ân. Karena itu, penulis akan mengurai satu persatu terlebih dahulu kedua kata tersebut secara definitif. Kata pragmatik itu sendiri didefinisikan oleh tiga pakar bahasa sebagai berikut:

Pertama, pendapat George Yule yang menyebutkan empat definisi, antara lain: (1) kajian terhadap maksud pembicara (speaker meaning), (2) kajian terhadap makna sesuai konteksnya (contextual meaning), (3) kajian terhadap makna yang diujarkan atau dikomunikasikan oleh pembicara (bow more gets communicated than is said), dan (4) kajian terhadap bentuk ekspresi sesuai jarak sosial yang membatasi partisipan yang terlibat dalam percakapan tertentu (the expression of relative distance). ${ }^{7}$

\footnotetext{
4 Abd Muqsith Ghazali, Metodologi Studi al-Qur'an (Jakarta: Gramedia Pustaka Agama, 2009), 119. Bandingkan 'Abd al-Ṣabûr Shâhîn, 'Arabiyyat al-Qur'an (t.t.: Maktabat alShahab, t.th.), 67.

5 Stephen C. Levinson, Pragmatics (Cambridge: Cambridge University Press, 1992), 21.

${ }^{6}$ Louis Cummings, Pragmatik: Sebuah Perspektif Multidisipliner, terj. Eti Setiawati (Yogyakarta: Pustaka Pelajar, 2007), 2.

${ }^{7}$ George Yule, Pragmatics (Oxford: Oxford Universty Press, 2006), 3-4.
} 
Kedua, Jenny Thomas membagi definisi pragmatik dengan dua bagian sesuai dengan kecenderungan masing-masing: (1) jika dilihat dari sudut pandang sosial, maka pragmatik berhubungan dengan makna pembicara (speaker meaning). (2) jika diamati dari perspektif kognitif, maka posisi prgamatik berhubungan dengan interpretasi ujaran (utterance interpretation). ${ }^{8}$ Karena itu, definisi pragmatik menurut Thomas adalah suatu disiplin keilmuan yang mengkaji makna dalam interaksi (meaning in action). Hal ini disebabkan pemaknaan merupakan proses dinamis yang melibatkan negosiasi antara pembicara dan pendengar serta antara konteks ujaran (fisik, sosial, dan linguistik) dan makna potensial yang muncul dari sebuah ujaran. ${ }^{\text {' }}$

Ketiga, Stephen C. Levinson mengemukakan definisi pragmatik dengan dua macam: (1) pragmatics is the study of the relations between language and context the are basic to an account of the language understanding (pragmatik adalah studi hubungan antara bahasa dengan konteks yang merupakan dasar penentuan pemahamannya). (2) pragmatics is the study of the ability of language users to pair sentences with the contexs in wich they would be appropriate (pragmatik adalah studi kemampuan para pengguna bahasa untuk menyesuaikan pasangan kalimat dengan konteks kebahasaan). ${ }^{10}$ Definisi pertama berorientasi pada appropriateness in meaning (ketepatan isi), yaitu apa yang harus dikatakan seorang penutur dalam situasi tertentu, seperti membicarakan pesta ulang tahun pada saat membesuk orang sakit. Sementara pada definisi kedua mengarah pada persoalan appropriateness in form (ketepatan bentuk), yaitu bagaimana seorang penutur dapat mengatakan sesuatu secara tepat, seperti memanggil "bos" pada seorang ustaz atau dosen.

Dari ketiga definisi di atas dapat disimpulkan bahwa pragmatik adalah suatu disiplin keilmuan yang mengkaji relasi bahasa dengan pengguna bahasa (language users), maksud pembicara (speaker meaning) dan relasi antar bahasa dengan konteks kebahasaaan (language context) yang menjadi dasar penentu pemahaman. ${ }^{11}$ Dengan demikian, keberadaan konteks kebahasaan merupakan komponen yang

8 Jenny Thomas, Meaning in Interaction: an Introduction to Pragmatics (New York: Longman, 1995), 2.

${ }^{9}$ Ibid., 22

${ }^{10}$ Levinson, Pragmatics, 31-34.

11 Bambang Kaswati Purwo, Pragmatik dan Pengajaran Bahasa: Menyibak Kurikulum 1984 (Yogyakarta: Kanisius, 1990), 15. Lihat juga Henry Guntur Tarigan, Pengajaran Pragmatik (Bandung: Angkasa, 1990), 33. Lihat juga Asim Gunarwan, Pragmatik: Pandangan Mata Burung (Jakarta: Unika Atmajaya, 1993), 3. 
signifikan dalam pemahaman mengingat suatu kata atau kalimat tidak akan lahir dalam ruang kosong (vacum cultural), tetapi berdialektika dengan realitas sosial yang mengitarinya. Karena itu, tugas mitra tutur dalam memahami bahasa tidak saja dituntut mengetahui makna kata berdasarkan relasi gramatikalnya saja, tetapi yang lebih objektif harus mampu menarik kesimpulan berdasarkan konteks kebahasaan.

Sementara definisi al-Qur'ân itu sendiri, sebagaimana yang ditawarkan oleh ahli fiqh dan ushul fiqh bahwa al-Qur'ân adalah firman Allah yang berupa mukjizat, diturunkan kepada Nabi Muhammad, tertulis dalam mushaf yang disampaikan secara mutawâtir dan bagi yang membacanya dinilai ibadah. Firman tersebut dimulai dari surat al-Fâtiḥah serta diakhiri dengan surat al-Nâs. ${ }^{12}$

Berdasarkan definisi dari kedua kata di atas, kesimpulan penulis bahwa pragmatika al-Qur'ân adalah suatu disiplin ilmu yang mengkaji al-Qur'ân dari sudut pandang relasi antara konteks linguistik (linguistic meaning) yang bersifat diadik dan konteks non-linguistik (speaker meaning) yang bersifat triadik. Konteks kebahasaan yang dimaksudkan penulis dalam kajian tersebut adalah susunan gramatikal ayat-ayat yang terdapat dalam al-Qur'ân, sedangkan konteks non-kebahasaan yaitu kajian terhadap situasi dan kondisi tertentu, baik sosial, geografis dan psikologi budaya Arab yang menjadi latar turunnya al-Qur'ân.

\section{Asumsi Dasar Pragmatika al-Qur'ân}

Kitab suci al-Qur'ân merupakan firman Allah yang menggunakan piranti kultural Bahasa Arab $^{13}$ dalam rangka merespons suatu kasus yang terjadi di Arab. Penggunaan piranti tersebut untuk memudahkan masyarakat Arab sebagai komunitas pengguna Bahasa Arab dalam melakukan interpretasi terhadap pesan-pesan moral al-Qur'ân. ${ }^{14}$ Dengan demikian, posisi al-Qur'ân merupakan media komunikasi dalam rangka merespons kasus yang terjadi dalam konteks lokalinsidental komunitas Mekkah dan Madinah.

\footnotetext{
12 Akram Khalîfah, Jam' al-Qur'ân: Dirâsah Taḅlîliyah li Marwiyyatih (Beirut: Dâr alKutub, 1427), 19. Lihat juga Nur al-Dîn 'Itr, Ulûm al-Qur'ân al-Karîm (Damaskus: Matba'at al-Sabah, 1414 H), 10. Bandingkan Fathurrosyid, "Eksistensi al-Qur'ân: Kajian Ontologi, Epistemologi, dan Aksiologi”, Studi al-Qur'ân (Surabaya: Kopertais IV Press, 2015), 12.

${ }^{13}$ Fathurrosyid, Semiotika Kisab al-Qur'ân: Membedah Perjalanan Religi Raja Sulaiman dan Ratu Balqis (Surabaya: Pustaka Radja, 2015), 3.

${ }^{14}$ Muhammad al-Ṭâhir b. 'Âshûr, Muḥammad al-Ṭahbir b. 'Âshûr al-Taḥrîr wa al-Tanwîr, Vol. 15 (Beirut: Mu’asasat al-Târîkh al-'Arabî, 2000), 106.
} 
Karena al-Qur'ân merupakan kitab suci yang menggunakan jaring lokalitas Arab, maka diperlukan perangkat sekunder untuk membongkar lapisan-lapisan pesan yang terendap dalam teks itu sendiri yang tidak dapat secara tuntas dipahami dari perspektif semantik teksnya. Hal ini dilakukan dalam rangka untuk mencapai titik subtilitas intelligendi (ketepatan pemahaman) dan subtilitas explicandi (ketepatan penjelasan) terhadap al-Qur'ân. Perangkat sekunder tersebut dalam kajian ilmu linguistik disebut kajian pragmatik. Asumsi dasarnya adalah sebagai berikut:

Pertama, al-Qur'ân adalah kitab suci yang tidak turun dalam ruang kosong (vacum cultural), akan tetapi mempunyai hubungan dialektis dengan realitas sosial-budaya; yaitu berinteraksi, bernegosiasi, dan berdialektika dengan kondisi sosial masyarakat Arab. ${ }^{15}$ Artinya, kondisi sosial, geografis dan psikologi masyarakat Arab ketika itu merupakan salah-satu pertimbangan menarik yang diangkat al-Qur'ân ke permukaan.

Berdasarkan fenomena di atas, upaya interpretasi terhadap kitab suci ini yang hanya diorientasikan pada analisis kelas struktur gramatikalnya tidak akan cukup memadai mengejar kebenaran hakiki yang diusung teks. Pencapaian terhadap makna-makna itu tidak cukup berdasarkan analisa struktur kalimatnya saja, tetap perlu dikembangkan pada analisa kelas, struktur sosial dan budaya melatari kehadiran teks tersebut. ${ }^{16}$ Analisa terhadap kelas, struktur sosial dan budaya tersebut dalam kajian linguistik disebut ilmu pragmatik, yaitu disiplin kajian yang terikat konteks (context dependent), ${ }^{17}$ baik konteks linguistik (linguistic meaning) yang bersifat diadik, maupun konteks nonlinguistik (speaker meaning) yang bersifat triadik.

Kedua, al-Qur'ân adalah kitab suci yang menggunakan media bahasa yang sarat makna (yahtamil al-wujūh li al-ma'nâa). Kondisi multiple meaning tersebut disebabkan faktor internal (al-'awâmil al-dâkbilîyah) kebahasaan ayat al-Qur'ân yang memberikan berbagai kemungkinan ruang kosong di satu sisi, serta adanya faktor eksternal (al-'awâmil alkhârijyyah) subjektivitas sang mufassir di sisi yang lain, sehingga

15 Muhammad Fârûq al-Nabhân, al-Madkhal lî al-Tashrî al-Islâmî (Beirut: Dâr alQalam, 1981), 83.

16 Ghazali, Metodologi Studi al-Qur'an, 119. Bandingkan Shâhîn, 'Arabiyyat al-Qur'ân, 67.

17 Thomas, Meaning in Interaction, 1-3. Lihat juga Patrick Griffiths, an Introduction to English Semantics and Pragmatics (Edinburgh: Edinburgh Universtiy Press, 2006), 1-6. Bandingkan Purwo, Pragmatik dan Pengajaran Bahasa, 16. 
muncul literatur tafsir yang kental dengan pewarnaan ideologis dan tendensius (talwînîyah mughridah), ${ }^{18}$ semisal tafsir yang bernuansa falsafî,

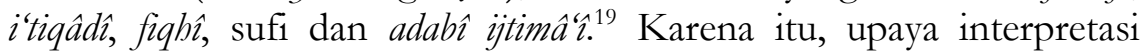
terhadap kitab suci ini tentu tidak akan pernah cukup untuk mendapatkan pemahaman yang objektif-totalistik jika hanya dikonsultasikan pada aspek strukturalnya saja. Sebab pembacaan secara struktural, hanya diorientasikan pada pemahaman posisi subjek, predikat dan objeknya saja, tanpa dinegosiasikan pada konteksnya. ${ }^{20}$

Kecuali itu, upaya interpertasi yang hanya mengandalkan pada analisa semantik, baik pada level kajian makna leksikal maupun makna gramatikal, juga tidak akan cukup ruang menemukan maqâsid al-sharîa yang dituju al-Qur'ân. Sebab kajian tersebut hanya terpusat pada kajian makna kata, klausa serta kalimat yang bebas konteks (contect independent). Sementara al-Qur'ân itu sendiri merupakan kitab suci yang diturunkan terikat konteks (contect dependet) mengingat ia diturunkan dalam rangka merespons realitas sosial komunitas Arab, sebagaimana kasus yang terjadi dalam Q.S. al-A'lâ [87]: 14-15. ${ }^{21}$ Karena itu, pemahaman yang didasarkan pada kajian pragmatik merupakan

18 Naṣr Hâmid Abû Zayd, al-Nașs, al-Sultah, al-Haqîqab: al-Fikrîyah al-Dînŷah bayn Irâdat al-Ma'rifah wa Irâdat al-Haymanah (Beirut: al-Markaz al-Thaqâfî, 1995), 120.

${ }^{19}$ Dalam konteks ini, literatur menarik yang membahas tentang corak dan ideologi penafsiran bisa dilihat misalnya, Muhammad Husayn al-Dhahabî, al-Tafsîr wa alMufassirûn (t.tp.: tp., 1396 H). 'Abd al-Qâdir Muḥammad Ṣâlih, al-Tafsîr wa alMufassirûn fì al-'Asr al-Hadith (Beirut: Dâr al-Ma'rifah, 1424 H). Ignaz Goldziher, Madhâbib al-Tafsîr al-Islâmî (Beirut: Dâr Iqra', 1403). Fahd 'Abd al-Raḥmân b. Sulaymân al-Rûmî, Ittijâhât al-Tafsîr fî̀ al-Qarn 'Asr (Riyad: Mu'asasat al-Risâlah, 1418). Lihat selengkapnya Mûsâ Ibrâhîm al-Ibrâhîm, Buhûth Manhajŷyah fî̀ Ulûm alQur'ân al-Karim (Amman: Dâr 'Ammar, 1996), 91-120.

20 Purwo, Pragmatik dan Pengajaran Bahasa, 11-12.

${ }^{21}$ Kalimat man tazakkêa dan fa sallâ yang terdapat dalam Q.S. al-A'lâ (87): 14-15 jika diinterpretasikan berdasarkan pemahaman struktural dan semantik, maka ia berarti perintah menunaikan zakat fitrah (tazakkêa) dan salat ied ( $f a$ sallâ) adalah tindakan pemahaman yang tidak objektif mengingat perintah kedua ritual tersebut baru diberlakukan sewaktu Rasulullah berhadapan dengan komunitas Madinah, sementara ayat tersebut diturunkan pada saat Rasulullah masih berdomisili di Mekkah. Karena itu, jika ayat tersebut dikonsultasikan dan negosiasikan pada konteksnya, maka-menurut pemahaman Ibn 'Abbâs-menunjukkan, bahwa kalimat tazakeka berorientasi pada kritik budaya politeisme (syirik) komunitas Mekkah dan kalimat fa sallâ berarti perintah ritual salat. Lihat selangkapnya Ibn alJawzî, Zâd al-Masîr fî̀ 'Ilm al-Tafsîr, Vol. 8 (Beirut: Dâr al-Fikr, 1407), 230. Lihat juga Musâ’id Sulaymân al-Ṭayyâr, al-Tafsîr al-Lughawî li al-Qur'ân al-Karim (Mekkah: Dâr Ibn al-Jawzî, t.th.), 30. 
pilihan tepat untuk menemukan "angan-angan sosial" al-Qur'ân yang sesungguhnya.

\section{Cara Kerja Pragmatika al-Qur'ân}

Konsep pragmatika al-Qur'ân dalam analisisnya mempunyai ragam tahapan atau cara kerja, yaitu analisis aspek sintaksis, dilanjutkan dengan analisis aspek semantis, kemudian dilakukan analisis pada aspek pragmatis. ${ }^{22}$ Cara kerja yang demikian dalam artikel ini penulis formulasikan sebagai berikut:

Pertama, konteks linguistik, yaitu pembacaan terhadap ayat alQur'ân, termasuk kisah Maryam, yang dikaji dengan menggunakan sudut pandang gramatikalnya yang meliputi sintaksis (naḅw), morfologi (sarf) dan semantik (mufradât). Hal ini dimaksudkan sebagai bahan kajian untuk mendapatkan pemahaman berdasarkan wujud formalnya.

Kedua, konteks non-linguistik, yaitu pembacaan ayat al-Qur'ân dilanjutkan pada enam dimensi, antara lain: tempat dan waktu (setting); pengguna bahasa (participants); topik pembicaraan (content); tujuan (purpose); nada (key); dan media (channel). ${ }^{23}$ Kajian terhadap enam dimensi konteks tersebut dalam kajian 'ulum al-Qur'ân disebut sabab al-

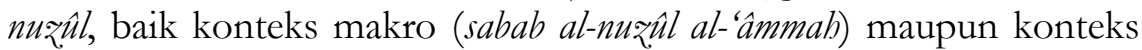
mikro (sabab al-nuðûl al-khâsşah). Wilayah kajian ini dimaksudkan untuk menemukan pesan moral objektif yang berada dibalik teks mengingat tidak semua teks bisa dipahami berdasarkan wujud formalnya.

Ketiga, analisis terhadap objek kajian pragmatika al-Qur'ân. Menurut Nababan, objek kajian yang disepakati tokoh linguistik dalam studi pragmatik meliputi empat hal; Pertama, deiksis. Kedua, implikatur. Ketiga, praanggapan. Keempat, tindak tutur. ${ }^{24}$ Namun demikian, penulis hanya membatasi pada kajian tindak tutur dan implikatur fragmentasi kisah Maryam saja.

\section{Tindak Tutur dan Implikatur: Pemahaman Kontekstual}

\footnotetext{
${ }^{22}$ Moh. Ainin, Fenomena Pragmatika dalam al-Qur'an (Malang: Misykat, 2010), 14-18.

23 Ronald Wardhaugh, an Introduction to Sociolinguistics (Hongkong: Blackwell Publishing, 2006), 242-248.

24 Bambang Kaswati Purwo, Deiksis dalam Bahasa Indonesia (Jakarta: PN Balai Pustaka, 1984), 10. Lihat juga PWJ. Nababan, Ilmu Pragmatik: Teori dan Penerapannya (Jakarta: Departemen Pendidikan dan Kebudayaan, 1987), 18.
} 
Tindak tutur (speech act) secara terminologis adalah pengucapan suatu kalimat yang tidak semata-mata menanyakan atau meminta jawaban tertentu, melainkan juga menindakkan sesuatu. ${ }^{25}$ Misalnya, ungkapan seorang ibu kos, "Sudah pukul 21.00, mas". Maksud kalimat tersebut tentu tidak semata-mata berfungsi sebagai kalimat informatif, tetapi juga mengandung makna imperatif; yaitu perintah agar pemuda tersebut hendaknya segara pulang meninggalkan tempat kos.

Persoalan yang muncul kemudian adalah bagaimana menentukan maksud dari aktivitas ujaran tersebut. Pertanyaan ini dijawab oleh Austin, bahwa dalam teori tindak tutur terdapat tiga klasifikasi tindakan yang dapat dilakukan melalui tuturan, ${ }^{26}$ yaitu: Pertama, Tindak Lokusi (locutionary acts), yaitu tindak mengucapkan sesuatu dengan kata, frasa dan kalimat sesuai dengan makna yang terkandung dalam kamus. Tindak tutur ini dapat disebut sebagai the act of saying something. Dengan demikian, pemahaman terhadap jenis tuturan ini hanya berbasis pada makna tekstual atau gramatikalnya saja.

Kedua, Tindak Illokusi (illocutionary acts), yaitu tindak tutur yang berfungsi melakukan sesuatu tindakan. Tindak tutur ini dapat dikatakan sebagai the act of doing something. Pemahaman terhadap tuturan ini harus dinegosiasikan dengan konteks yang ada. Misalnya, tuturan "Tanganku gatal!". Tuturan tersebut jika dipahami dalam konteks lokusi berarti menunjukkan kalimat informatif, bahwa tangannya gatal. Sementara jika dipahami dalam konteks illokusi menunjukkan bahwa penutur menginginkan mitra tuturnya agar mengambilkan obat penghilang rasa gatal. Tindak tutur illokusi ini, diklasifikasikan oleh Searle ${ }^{27}$ ke dalam lima macam bentuk tuturan sebagai berikut: (1) Asertif (assertives), yakni tuturan yang mengikat penutur pada kebenaran proposisi yang diungkapkan, misalnya: menyatakan, menyarankan, membuang, mengeluh, mengadu dan mengklaim. (2) Direktif (direktives), yakni tuturan yang dimaksudkan untuk membuat pengaruh agar sang mitra tutur melakukan tindakan tertentu, misalnya memesan, memerintah, memohon, menasihati, dan

25 Yule, Pragmatics, 47-48. Bandingkan Rustono, Pokok-pokok Pragmatik (Semarang: IKIP Semarang Press, 1999), 33.

26 Thomas, Meaning in Interaction, 49. Bandingkan Jacob L. Mey, Pragmatics: an Introduction (Hongkong: Blackwell Publishing, 2001), 120-122. Bandingkan Abdul Chaer, Sosiolinguistik: Perkenalan Awal (Jakarta: Rineka Cipta, 2004), 56-60.

27 Charles W. Kreidler, Introducing English Semantic (London: Routledge, 1998), 183 192. 
merekomendasi. (3) Ekspresif (expressives), yakni tuturan yang berfungsi menyatakan atau menunjukkan sikap psikologis penutur terhadap suatu keadaan, misalnya berterima kasih dan memberi selamat. (4) Komisif (commissives), yakni tuturan yang berfungsi menyatakan janji atau penawaran, misalnya berjanji, bersumpah, dan menawarkan sesuatu. (5) Deklarasi (declarations), yakni tuturan yang menghubungkan isi tuturan dengan kenyataannya, misalnya berpasrah, memecat, membaptis, memberi nama, mengangkat, mengucilkan, dan menghukum.

Ketiga, tindak perlokusi (perlocutionary acts), yaitu tuturan yang memiliki efek yang ditimbulkan dari sebuah tuturan, baik disengaja atau tidak yang disebut dengan the act of effecting someone. Tuturan “Tanganku gatal!" bisa menimbulkan efek rasa takut pada mitra tutur, karena tuturan itu diucapkan oleh seorang tukang pukul.

Dengan demikian, suatu pernyataan dapat dipahami dengan sempurna bilamana pernyataan tersebut dipahami konteksnya. Artinya, seorang mitra tutur harus bisa memahami kapan pernyataan itu diucapkan, kepada siapa dan bagaimana maksudnya. Dengan cara yang seperti itu, problem kebahasaan (misunderstanding) dapat kita carikan solusi dengan sebaik-baiknya, sehingga dengan cara "memangkas" problem tersebut, juga akan diperoleh pemahaman sebenar-benarnya sesuai dengan keinginan sang penutur.

Sedangkan yang dimaksud dengan implikatur adalah suatu proposisi yang diimplikasikan oleh suatu tuturan dalam suatu konteks dan proposisi tersebut bukan merupakan bagian dari tuturan itu sendiri. ${ }^{28}$ Artinya, posisi implikatur merupakan suatu kajian terhadap suatu ujaran yang menyiratkan sesuatu yang berbeda dengan ucapan yang sebenarnya. ${ }^{29}$ Sedangkan urgensi posisi implikatur dalam kajian pragmatik disebabkan empat hal: Pertama, dapat menjelaskan faktafakta bahasa secara fungsional. Kedua, dapat menjelaskan makna secara implisit dari bahasa eksplisit. Ketiga, dapat menyederhanakan deskripsi dari sisi struktur maupun substansi makna. Keempat, dapat memberikan penjelasan berbagai dasar fakta kebahasaan yang tidak relevan secara struktural tetapi mempunyai relevansi secara faktual. ${ }^{30}$

\section{Bayi yang Tidak Dirindukan: Akses Menyuarakan Kekecewaan}

28 Gerald Gazdar, Pragmatic Implicature: Presupposition and Logical Form (New York: Academic Press, 1979), 38. Lihat juga Mey, Pragmatics, 45.

${ }^{29}$ Purwo, Deiksis dalam Bahasa Indonesia, 2.

${ }^{30}$ Levinson, Pragmatics, 31. 
Situasi dan kondisi Hannah sewaktu melahirkan bayi berjenis kelamin perempuan dikisahkan dalam potongan ayat Q.S. Âli 'Imrân [03): 36, sebagaimana berikut:

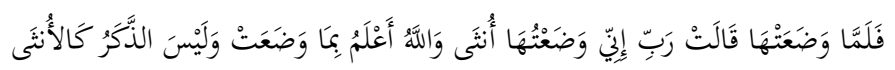

"Maka tatkala istri Imran melahirkan anaknya, diapun berkata: "Ya

Tuhanku, Sesunguhnya aku melahirkannya seorang anak perempuan; dan Allah lebih mengetahui apa yang dilahirkannya itu; dan anak lakilaki tidaklah seperti anak perempuan".

Jika potongan ayat dalam Q.S. Âli 'Imrân [03]: 36 tersebut dibaca dengan menggunakan teori pragmatika tindak tutur, maka lokusi kalimat tersebut menunjukkan kalimat informatif (khabariyah). Dalam konteks kisah tersebut, potongan kalimat innî wada'tuhâ unthâ, secara gramatikal berdasarkan wujud formalnya, Hannah melaporkan kepada Allah bahwa dirinya melahirkan seorang anak perempuan. Artinya, begitu bayi terlahir, ia menginformasikan bayi tersebut berjenis kelamin perempuan.

Sementara itu, jika potongan ayat di atas dibaca menggunakan teori tindak tutur illokusi menunjukkan bentuk kalimat asertif (assertives) yang bermakna mengeluh (complaining). Munculnya ekspresi keluhan tersebut disebabkan oleh faktor rasa kesedihan, penyesalan dan kekecewaan Hannah atas kelahiran bayi yang tidak dirindukan. Sebab bayi yang diimpikan berjenis kelamin laki-laki (male), tetapi justru yang dilahirkannya berjenis kelamin perempuan (feminin). Dengan demikian, potongan ayat tersebut bukan kalimat yang berbentuk informatif-deklaratif (al-ikhbâr wa al-ilâm), tetapi kalimat asertif (assertives) yang bermakna mengeluh (complaining) sebagai bentuk ungkapan rasa penyesalan (li al-itiz̧âr wa al-tahassur) atas kandasnya harapan Hannah. ${ }^{31}$

Berbeda dengan lokusi dan illokusi yang bersifat the act of saying dan the act of doing something, tindak tutur perlokusi yang berorientasi pada the act of affecting someone, memberikan satu efek agar Allah memperhatikan penyesalan dan permohonan Hannah. Dalam konteks ini, efek tersebut tampak ketika Allah memberikan respons dengan firman-Nya, "dan Allah lebih mengetahui apa yang dilahirkannya itu (wa Alâh a 'lam bimâ wada'at). Kata wada'at jika dibaca sukûn huruf tâ'nya (baca: wada'at), maka ideal moral-nya sesungguhnya menunjukkan makna reaksi resistensi Allah terhadap kesedihan yang ditampakkan

31 al-Râzî, Mafâtîh al-Ghayb, Vol. 8, 204. 
Hannah, bahwa kelahiran bayi perempuan ini bersifat by design $n^{32}$ yang dipersiapkan nantinya untuk melahirkan sosok bernama Isa al-Masih.

Adapun jika potongan ayat ini dibaca menggunakan implikatur, maka ayat ini merupakan bentuk feminisme yang ditampilkan oleh Maryam sebagai perempuan yang punya hak untuk mengekspresikan kekecewaannya. Ia ditampilkan dalam fragmen kisah ini tidak menjadi aktor perempuan yang dibungkam oleh sistem teologis dan sosiologis. Situasi demikian tentu jauh berbeda dengan situasi dan kondisi yang terjadi di masyarakat kala itu, karena dalam konstruk masyarakat perempuan yang baik adalah perempuan yang halus dan lembut, tidak mudah protes terhadap kegagalan yang dialaminya. Menyuarakannya adalah tindakan tabu dan mencederai eksisitensi perempuan sebagai sosok yang pasrah terhadap keadaan. Namun sekalipun begitu, kebebasan berpendapat dalam konteks ini tidak berarti harus bebas nilai (free value). Ekspresi kekecewaan Maryam disampaikan dengan cara-cara yang sopan dan santun, sehingga susunan kalimatnya tidak satupun yang dirangkai menggunakan kalimat pertanyaan berupa; kenapa dan mengapa Engkau memberikan aku seorang anak perempuan?.

\section{Bayi Mungil Diberi Nama Maryam: Akses Perlawanan terhadap Tradisi Misoginis}

Labelisasi nama "Maryam" yang diberikan oleh Hannah dikisahkan dalam potongan ayat Q.S. Âli 'Imrân [03]: 36, sebagaimana berikut;

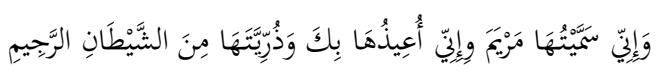

"Sesungguhnya aku telah menamai dia Maryam dan aku mohon perlindungan untuknya serta anak-anak keturunannya kepada (pemeliharaan) Engkau dari setan yang terkutuk."

Ayat di atas mendeskripsikan tentang situasi pasca-lahirnya bayi perempuan yang dikandung oleh Hannah. Setelah Hannah mengekspresikan rasa sedih dan kekecewaan karena melahirkan bayi yang tidak dirindukan tersebut, maka pada potongan ayat ini, beliau menegaskan bahwa bayinya diberi nama "Maryam". Kemudian ia berdoa agar bayi serta keturunannya kelak terlindungi dari gangguan setan.

Jika ayat di atas dibaca dengan menggunakan teori tindak tutur, maka lokusinya menunjukkan kalimat informatif (khabarîyah), karena

32 'Abd al-Karîm al-Khațîb, al-Tafsîr al-Qur'ânî li al-Qur'ân, Vol. 2 (Kairo: Dâr al-Fikr al-'Arabî, t.th.), 436. 
Hannah menginformasikan bahwa bayinya diberi nama "Maryam". Sementara bentuk ilokusinya merupakan kalimat deklaratif (declarations) yang berfungsi untuk memberi nama (naming) dan berbentuk direktif (directives) yang berfungsi untuk memohon (requesting). Hal ini dikarenakan labelisasi nama "Maryam" dalam tradisi bahasa mereka saat itu disebut sebagai pelayan Tuhan (khâdim al-rabb) yang berarti perempuan yang tekun beribadah. Sekalipun demikian Hannah telah menyadari sosok perempuan memang tidak pantas berkhidmat di tempat ibadah (al-kanîsab), ${ }^{33}$ namun dengan cara labelisasi nama Maryam ini diharapkan agar terjadi kesesuaian antara perilaku dan pesan moral namanya, sehingga tidak terhalang menjadi perempuan yang tekun beribadah. ${ }^{34}$

Berbeda dengan teori lokusi yang befungsi informatif (khabarŷah) dan illokusi yang berfungsi permohonan (insyâ), maka perlokusinya merupakan bentuk respons dan reaksi Allah terhadap permohonan tersebut. Hal ini dapat dibuktikan dalam adegan kisah yang terdapat dalam Q.S. Âli 'Imrân [03]: 37. Kisah dalam ayat tersebut menceritakan kehidupan Maryam yang berada dalam asuhan seorang Nabi Zakariya.

Sedangkan implikatur dari kisah pemberian nama Maryam menunjukkan, bahwa Hannah ingin membentur tradisi patriarkis yang bersifat misoginis. Tradisi kebencian seorang suami terhadap anak telah menghegemoni masyarakat kala itu. Karena itu, pada saat yang sama Hannah tampil dengan tegas memberi nama sendiri kepada bayi perempuannya dengan sebutan Maryam, ${ }^{35}$ sebagai bukti resepsi ketulusan atas kehadiran bayi tersebut. Hannah menunjukkan pada publik bahwa sekalipun bayi yang dilahirkannya berjenis kelamin perempuan, ia tetap optimis menatap masa depan anaknya dengan tegas menyatakan innî sammaytubâ Maryam.

\section{Berkhidmat di Bayt al-Maqdis: Akses Teologis-Edukatif}

Nazar ingin menginvestasikan anak untuk berkhidmat di Baitul Maqdis yang pernah diucapkan oleh Hannah yang dikisahkan dalam Q.S. Âli 'Imrân [03]: 35 kini benal-benar diterima oleh Allah swt..

\footnotetext{
33 Luṭf Allâh al-Qinnûjî, Fatḥ al-Bayân fî̀ Maqâsid al-Qur'ân, Vol. 2 (Beirut: alMaktabah al-'Așrîyah, 1412), 223.

34 Muhammad Jamâl al-Dîn b. Muhammad Saî̀d b. Qâsim al-Ḥallâq al-Qâsimî, Maḥâsin at-Ta'mîl, Vol. 4 (Beirut: Dâr al-Kutub al-'Ilmîyah, 1418 H), 133.

35 Abû Hayyân al-Andalûsî, Tafsîr al-Bạ̣r al-Muḥ̂t, Vol. 2 (Beirut: Dâr al-Fikr, 1420 H), 333 .
} 
Terkabulnya nazar tersebut dijelaskan dalam Q.S. Âli 'Imrân [03]: 37, sebagaimana firman Allah berikut ini:

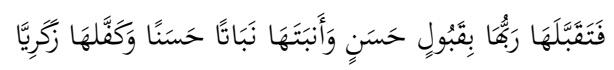

"Maka Tuhannya menerimanya (sebagai nazar) dengan penerimaan yang baik, dan mendidiknya dengan pendidikan yang baik, serta Allah menjadikan Zakariyya sebagai pengasuhnya".

Ayat di atas dalam teori tindak tutur, lokusinya menunjukkan kalimat informatif (khabariyah), bahwa Allah menerima nazar Hannah dengan penuh kerelaan dan juga diterima dengan senang hati (qabull hasan). Illokusinya merupakan kalimat asertif (assertives), yakni tuturan yang mengikat penutur pada kebenaran proposisi yang diungkapkan. Dalam konteks ini, Allah mendeklarasikan penerimaan bayi mungil bernama Maryam berkhidmat di Bayt al-Maqdis. Sedangkan perlokusinya adalah terpilihnya Nabi Zakariyya yang mengalahkan tokoh-tokoh lainnya dalam mengasuh, membina, dan mendidik Maryam. Potongan ayat wa anbatahâ nabâtan ḥasanan wa kaffalabâ zakariyya menunjukkan sosok Maryam memang diproyeksikan dan direkayasa oleh Allah tumbuh dan berkembang sebagai anak yang terpelihara dari segala kejelekan. Ibarat suatu pohon yang tumbuh dan berkembang di tempat yang baik, maka pohon tersebut akan memberikan buah yang baik pula. ${ }^{36}$

Adapun implikatur fragmentasi kisah yang terdapat dalam potongan ayat di atas menunjukkan, bahwa bayi yang dinazarkan oleh Hannah telah diterima di sisi Allah dengan penuh kerelaan serta dengan senang hati, sekalipun bayi yang dilahirkannya berjenis kelamin perempuan yang dalam tradisi masyarakat waktu itu tidak bisa diterima menjadi sosok yang berkhidmat di Bayt al-Maqdis, kecuali seorang laki-laki. ${ }^{37}$ Dengan demikian, melalui ayat ini, Allah ingin memberikan pelajaran berharga, bahwa posisi perempuan setara (equal) dengan posisi laki-laki untuk memperoleh akses seluas-luasnya dalam bidang pemberdayaan pendidikan. Potongan ayat di atas merupakan kritik terhadap konstruk masyarakat kala itu yang menempatkan posisi perempuan berada dalam wilayah privat an sich.

\section{Superioritas Maryam: Akses Spritual di Wilayah Publik}

Setelah Allah menguraikan karakteristik dan hak superioritas khusus yang diberikan pada Maryam dalam Q.S. Âli 'Imrân [03]: 42,

\footnotetext{
36 Muhammad Saî̀d al-Tantâwî, al-Tafsîr al-Wasit li al-Qur'ân al-Karîm, Vol. 2 (Kairo: Dâr Nahḍat Miṣr li al-Ṭibâ'ah wa al-Nashr wa al-Tawzî‘, 1998), 89.

${ }^{37}$ al-Râzî, Mafâtîh al-Ghayb, Vol. 8, 26.
} 
maka pada Q.S. Âli 'Imrân [03]: 43 Allah menjelaskan kewajiban yang harus dikerjakannya, ${ }^{38}$ sebagaimana dinarasikan dalam ayat berikut:

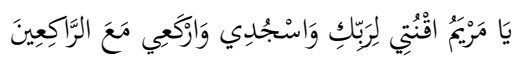

Hai Maryam, taatlah kepada Tuhanmu, sujud dan rukulah bersama orang-orang yang ruku.

Ayat di atas jika dibaca menggunakan teori tindak tutur, maka lokusi ayat tersebut menunjukkan ucapan malaikat kepada Maryam yang berbentuk interogatif agar ia melaksanakan qunut, sujud dan ruku. Sementara bentuk illokusinya berupa kalimat asertif yang berbentuk mengklaim, bahwa Maryam merupakan profil perempuan spritualis dan asketis. Adapun bentuk perlokusinya yaitu respons atau rekasi yang ditunjukkan oleh Maryam terhadap perintah tersebut, sehingga Maryam mengerjakannya dengan tulus tanpa pamrih. Perjuangan itu dilakukan secara konsisten dan intensif, bahkan sampai berdarah-darah. Menurut al-Awzâî, perintah malaikat itu dilaksanakan oleh Maryam hingga tumitnya membengkak, berdarah dan bernanah, ${ }^{39}$ karena ia sudah merasakan betapa nikmatnya beribadah kepada Allah.

Sedangkan jika dibaca dengan menggunakan teori implikatur, ayat di atas menunjukkan perintah kepada Maryam agar mengerjakan salat secara individual yang disimbolkan dengan kalimat uqnutî wa usjudî, serta perintah mengerjakan salat secara kolektif yang dilambangkan dengan kalimat wa irkầ ma'a al-râkiî̀n. Hal ini-menurut Ibn 'Atîyah-dikarenakan penggunaan kalimat uqnutî yang bermakna hendaklah berdiri lama dalam salat merupakan simbol perintah mengerjakan salat secara individual atau sendirian. Sebab tidak mungkin menyuruh mengerjakan salat dalam waktu yang relatif lama jika itu dilaksanakan secara kolektif atau berjemaah. ${ }^{40}$ Dengan demikian, implikatur kalimat uqnutî wa usjudî merupakan bentuk perintah mengerjakan salat secara individual atau sendirian, sedangkan bentuk kalimat wa irka $\hat{\imath}$ ma'a al-râki'în merupakan perintah melaksanakan salat secara kolektif atau berjemaah.

\footnotetext{
38 Muhammad Husayn al-Ṭabâtabâ'î, al-Mîzân fî̀ Tafsîr al-Qur'ân, Vol. 3 (t.t. Manshûrât Muassasat al-A 'lamî li al-Maṭû́ât, 1997), 160.

39 Ṣâdiq Khân, Fatḥ al-Bayân fî Maqâsid al-Qur'ân, Vol. 2 (Beirut: al-Maktabah al'Așrîyah, 1412 H), 233. Lihat juga Muhammad Husayn al-Baghawî, Ma'âlim alTan₹̂́l, Vol. 2 (Beirut: Dar Ṭayyibah, 1417 H), 37.

40 al-Andalûsî, Tafsîr al-Bạ̣r al-Muhît, Vol. 3, 148. Lihat juga Abû Zayd al-Tha'âlabî, al-Jawâhir al-Hisân fì Tafsîr al-Qur'ân, Vol. 2 (Beirut: Dâr Ihyầ' al-Turâth, 1418 H), 44.
} 
Di samping itu pula, ayat ini juga menunjukkan superioritas Maryam, sehingga ia diberikan legislasi untuk melaksanakan salat berjemaah. Sebab posisi Maryam dihitung setara dengan posisi lakilaki mengingat kesempurnaan dan kelebihan yang dimilikinya. Itulah sebabnya mengapa dalam konteks ayat ini, kalimat wa irka'î ma'a alrâki'în diekspresikan dengan menggunakan redaksi yang berbentuk maskulin (ma'a al-râki'în), bukan berbentuk feminin (ma'a al-râki'ât). ${ }^{41}$ Dengan demikian, ayat di atas merupakan bukti nyata, bahwa pada masa Bani Israil terdapat seorang perempuan yang diberikan kebebasan untuk terlibat ke dunia publik melaksanakan salat berjemaah secara kolektif.

Kecuali itu, implikatur ayat di atas juga menegaskan tentang posisi Maryam sebagai hamba Allah bukan sebagai istri Tuhan yang melahirkan anak bernama Isa as. Penyebutan nama Maryam dalam alQur'ân serta terdokumentasinya menjadi "Surat Maryam” merupakan binary opposition terhadap tradisi masyarakat yang tidak mem-publish nama istrinya di lingkungan kerajaan atau masyarakat terpandang waktu itu. Tradisi mereka hanya biasa mempublikasikan nama budaknya. ${ }^{42}$ Karena itu, ketika masyarakat menuduh Maryam sebagai istri Tuhan, maka untuk membantah tuduhan peyoratif tersebut, dengan tegas Allah menyebut dan mempublikasikan nama Maryam, sebagai bentuk logika oposisi biner, bahwa status Maryam sebagai budak atau hamba Allah semata, bukan berstatus sebagai istri-Nya.

\section{Dialog Maryam dan Jibril: Akses Resistensi terhadap Pelecehan Seksual}

Kisah ini dimulai dari sikap kekhawatiran dan ketakutan yang dialami oleh Maryam ketika beliau melihat seorang lelaki datang menemui dirinya. Ketakutan tersebut dikisahkan dalam Q.S. Maryam [19] ayat 18 , sebagai berikut:

\footnotetext{
${ }^{41}$ Ibn 'Âshûr, Tafsîr al-Taḅrîr wa al-Tanwîr, Vol. 3, 95. Lihat juga Fâdil Ṣâlih al-Sâmirî, Lamsât Bayânîyah li Sûrat al-Qur'ân, Vol. 1 (Beirut: Dâr al-Fikr, t.th.), 104.

42 Muhammad b. Aḥmad al-Anșârî al-Qurțubî, al-Jâmi‘ li Aḅkâm al-Qur'ân, Vol. 4 (t.t.: Muassasat al-Risâlah, 2006), 22. Lihat juga al-'Alwî al-Hararî, Tafsîr Hadâ'iq alRûh wa al-Raỵ̣ân fî̀ Rawâbî 'Ulum al-Qur'ân, Vol. 17 (Beirut: Dâr Tûq al-Najâh, 1421), 100. Lihat juga al-Ḥanafî al-Khalwatî, Tafsîr Rûh al-Bayân, Vol. 5 (Beirut: Dâr Ihyầ', t.th.), 247. Lihat juga Ibn Muștafâ al-Zuhaylî, Tafsîr al-Munîr fi al-'Aqî̉ah wa alSharîah wa al-Manhaj, Vol. 6 (Damaskus: Dâr al-Fikr al-Mu'așir, 1418), 48. Lihat juga Muhạmmad Alî al-Ṣâbûnî, Șafwat al-Tafâsîr, Vol. 2 (Mekkah: Dâr al-Ṣâbûnî, t.th.), 130.
} 


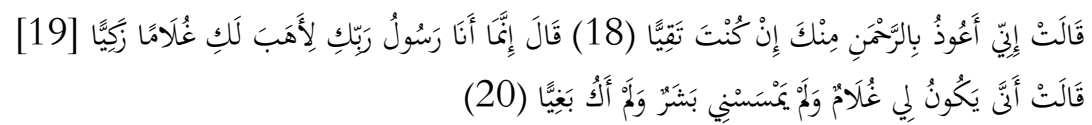

"Maryam berkata: "Sesungguhnya aku berlindung dari padamu kepada Tuhan Yang Maha pemurah, jika kamu seorang yang bertakwa." Ia (Jibril) berkata: "Sesungguhnya aku ini hanyalah seorang utusan Tuhanmu, untuk memberimu seorang anak laki-laki yang suci". Maryam berkata: "Bagaimana akan ada bagiku seorang anak laki-laki, sedang tidak pernah seorang manusiapun menyentuhku dan aku bukan (pula) seorang pezina!".

Allah menceritakan situasi dan kondisi dialog yang terjadi antara Maryam dan Malaikat Jibril yang sudah menjelma menjadi manusia berjenis kelamin laki-laki. ${ }^{43}$ Kedatangan lelaki tersebut sempat membuat hati Maryam bingung dan galau, sebab ia mengira bahwa kehadiran lelaki itu dalam kondisi yang sepi, dikhawatirkan hanya akan mengancam stabilitasnya, menggoda dan mengganggunya. ${ }^{44}$ Karena itu dalam konteks ayat Q.S. Maryam [19]: 18, Maryam menyampaikan pesan berupa kalimat, "Sungguh saya berlindung kepada Dzat yang Penyayang dari kamu, jika kamu benar-benar orang yang takwa dan takut kepada Allah". ${ }^{45}$

Sementara jika dilihat dari teori tindak tutur, lokusi ayat ini pada dasarnya merupakan bentuk kalimat yang bersifat informatif (khabarîyah) yang berarti posisi Maryam sebagai seorang yang memberikan informasi bahwa dirinya menjadikan Allah sebagai Dzat yang memberi perlindungan dari perilaku negatif lelaki tersebut. Sedangkan illokusi ayat ini merupakan kalimat direktif yang berisfat memberi nasehat $\left(\right.$ advising) ${ }^{46}$ berdasarkan penggunaan kalimat bersyarat berupa kata in kunta taqiyyan.$^{47}$ Dalam konteks ini, Maryam memberi nasehat dan peringatan agar lelaki tersebut hendaknya bertakwa kepada Allah. Dalam diri orang yang bertakwa, jika diingatkan dengan kalimat perlindungan kepada Allah, maka dia tidak akan melakukan tindakan yang dapat mendatangkan murka-Nya, ${ }^{48}$ sehingga dengan cara yang demikian, secara psikologis dapat

\footnotetext{
43 al-Ṭantâwî, al-Tafsîr al-W asît, Vol. 9, 24.

${ }^{44}$ Abû Ja'far al-Ṭabarî, Jâmi al-Bayân fî Ta'wîl al-Qur'ân, Vol. 15 (t.t.: Muassasat alRisâlah, 2000), 487.

45 al-Ṭantâwî, al-Tafsîr al-Wasît, Vol. 9, 24.

${ }^{46} \mathrm{Ibn}$ 'Âshûr, Tafsîr al-Tahrîr wa al-Tanwîr, Vol. 16, 22.

47 'Abd al-Qâhir al-Jurjânî, Darj al-Darar fî Tafsîr al-Ayyi wa al-Suwar, Vol. 2 (Amman:

Dâr al-Fikr, 1430), 265.

${ }^{48}$ al-Ṭabâtabâ'î, al-Mìzân fí Tafsìr al-Qur'ân, Vol. 3, 203.
} 
membebaskan rasa ketakutan yang mengancam dirinya. Adapun perlokusi ayat ini atau efek yang ditimbulkan dari ungkapan tersebut, yaitu resistensi yang disampaikan oleh laki-laki tersebut dan mengklaim bahwa semua tuduhan yang disampaikan oleh Maryam tidak benar, sebagaimana penjelasan pada ayat berikutnya, Q.S. Maryam [19]: 19.

Berbeda dengan teori tindak tutur, ayat ini jika ini dibaca dengan teori implikatur menunjukkan kesempurnaan kepribadian sosok Maryam yang mampu menjaga harga dirinya dari perbuatan keji. Beliau adalah perempuan yang mempunyai konsistensi untuk selalu berada dalam perlindungan dan pengawasan Allah. ${ }^{49}$ Maryam mengira lelaki yang datang itu menyembunyikan suatu perasaan untuk menggoda dirinya. Karena itu Maryam langsung melontarkan suatu pernyataan kalimat perlindungan kepada lelaki tersebut sebelum ia berbicara tentang banyak hal dengan dirinya. Hal ini dimaksudkan untuk menepis dugaan tujuan negatif yang ingin dicapai lelaki tersebut. ${ }^{50}$ Dengan demikian, dalam konteks ini Maryam dijadikan sebagai representasi simbol perlawanan kaum perempuan terhadap segala bentuk pelecehan seksual yang terjadi dalam dunia perempuan.

Perlawanan yang dilakukan oleh Maryam tidak hanya sampai di sini, ia lebih tegas lagi ketika malaikat Jibril menginformasikan, bahwa kedatangan Jibril hanya sebatas utusan Allah, agar memberikan anak yang suci, sebagaimana dikisahkan dalam Q.S. Maryam [19]: 19. Informasi tersebut dijawab dengan tegas oleh Sayyidah Maryam dalam Q.S. Maryam [19]: 20 sebagai berikut:

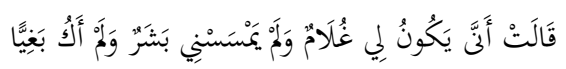

"Bagaimana akan ada bagiku seorang anak laki-laki, sedangkan tidak pernah seorang manusiapun menyentuhku dan aku bukan (pula) seorang pezina!.".

Kisah Maryam di atas menunjukkan bahwa ia menyuarakan aspirasinya, sehingga ia mempersoalkan proses penciptaan bayi mungil tersebut, karena dilihat dari perspektif sosiologis dan biologis, kelahiran seorang anak harus dilakukan dengan dua proses: Pertama, cara pernikahan yang dihalakan oleh agama, yaitu melalui proses akad dan persaksian. Kedua, cara perzinahan yang diharamkan oleh agama. Berangkat dari realitas ini, Maryam meminta penjelasan secara

49 Muhammad Mutawallî al-Sha'râwî, Tafsîr al-Sha'râmî, Vol. 1 (Kairo: Akhbâr alYawm, 1991), 5521-5522.

${ }^{50} \mathrm{Ibn}$ 'Âshûr, Tafsîr al-Taḥîr wa al-Tanwîr, Vol. 16, 21. 
argumentatif tentang proses pemberian anak tersebut mengingat kedua cara kelahiran anak yang lumrah terjadi di masyarakat, tidak pernah beliau lakukan, bahkan dengan tegas beliau menegaskan dan menafikan posisi dirinya sebagai perempuan pelacur. ${ }^{51}$

Adapun jika kisah di atas dibaca dengan menggunakan teori tindak tutur, maka lokusinya merupakan bentuk permohonan informasi proses pemberian seorang anak pada saat dirinya tidak pernah melakukan hubungan intim dengan seorang laki-laki. Dalam konteks ini, Maryam mempersoalkan status pemberian anak tersebut, apakah akan diberikan nanti setelah melalui proses pernikahan terlebih dahulu dengan seorang lelaki yang tiada di sangka-sangka sebelumnya ataukah semata-mata murni kekuasaan Allah, sebagaiamana penciptaan Nabi Adam yang tanpa keterlibatan seorang bapak dan ibu. Sementara illokusinya merupakan kalimat yang berbentuk deklarasi yang bertujuan untuk menunjukkan kepasrahan dan kekagumannya kepada kekuasaan Allah. ${ }^{52}$ Sedangkan perlokusinya adalah pernyataan Jibril bahwa Allah berkuasa menciptakan segala sesuatu sesuai dengan ketetapan-Nya, sebagaimana penjelasan pada ayat berikutnya, Q.S. Maryam [19]: 21. Karena itu, pada ayat tersebut Jibril tidak menjelaskan secara detail tentang proses penciptaan bayi mungil yang akan diberikan kepada Maryam.

Berbeda dengan kedua teori di atas, kisah yang terdapat dalam ayat ini jika dibaca dengan teori implikatur menunjukkan bahwa, Maryam adalah seorang perempuan yang tegas dan tidak mudah terbawa arus godaan begitu datang rayuan yang bertubi-tubi dari seorang laki-laki. Indikator yang menunjukkan ke arah tersebut adalah penggunaan kalimat wa lam aku bagiyyan. Pernyataan tersebut disampaikan Maryam untuk menafikan bahwa semenjak dulu dirinya bukan seorang perempuan asusila, dan itu akan dipertahankannya hingga masa yang akan datang. Ia tidak rela jika dicap sebagai pelacur, baik pada saat pertemuannya denga Jibril maupun nanti pada masa yang akan datang. ${ }^{53}$

\section{Menggoyangkan Pohon Kurma: Upaya Mencegah Gizi Buruk}

Kisah ini disajikan dalam bentuk kalimat larangan bersedih dan perintah menggoyangkan pohon kurma dalam Q.S. Maryam [19]: 2425, sebagai berikut:

\footnotetext{
51 al-Sha'râwî, Tafsîr al-Sha'râmî, Vol. 1, 5524.

52 Ibid.

${ }^{53}$ Ibn 'Âshûr, Tafsîr al-Taḥîr wa al-Tanwîr, Vol. 16, 23.
} 


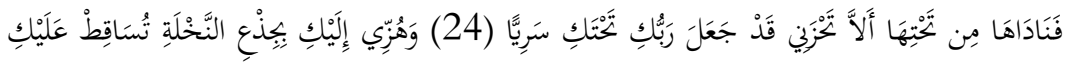

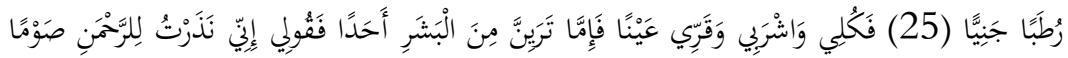

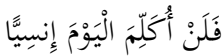

"Maka Jibril menyerunya dari tempat yang rendah: "Janganlah kamu bersedih hati, sesungguhnya Tuhanmu telah menjadikan anak sungai di bawahmu. Dan goyanglah pangkal pohon kurma itu ke arahmu, niscaya pohon itu akan menggugurkan buah kurma yang masak kepadamu". ${ }^{54}$

Setelah bayi yang dikandung Maryam terlahir ke dunia pada waktu tergelincirnya matahari, ${ }^{55}$ tiba-tiba terdengar suara "seseorang" dari tempat yang rendah, sebagaimana dikisahkan dalam Q.S. Maryam [19]: 24. Dalam ayat tersebut tidak ada penjelasan secara detail tentang siapa yang berbicara. Namun demikian, ada sebagian mufassir yang meyakini bahwa yang berbicara dengan Maryam itu adalah Malaikat Jibril. ${ }^{56}$ Alasannya, posisi Jibril pada saat itu seakan-akan sebagai seseorang yang menyambut kedatangan sang bayi. Di samping itu, mereka juga mengklaim bahwa Nabi Isa bisa berbicara hanya sewaktu beliau disuruh oleh Maryam agar berbicara dihadapan publik nantinya. ${ }^{57}$

Berbeda dengan mufassir minoritas, kelompok mufassir mayoritas mengklaim bahwa yang berbicara tersebut adalah bayi yang bernama Isa as itu sendiri, dengan beberapa argumen; Pertama, berdasarkan logika bahasa dengan prinsip kedekatan rujukan pada ayat sebelumnya, yaitu posisi ism damîr "hu" yang dikembalikan kepada Nabi Isa. Dengan cara yang demikian, maka dalam konteks ayat ini tentu juga kembali kepada Nabi Isa. Kedua, berdasarkan logika empiris-eksprimentatif. Artinya, keberanian Maryam menyuruh bayinya berbicara dihadapan publik, sebagaimana dikisahkan pada ayat berikutnya, didasarkan pada fakta empiris dan eksperimentatif pada ayat ini tentang kemampuan Isa yang sudah bisa berbicara sewaktu dilahirkan sebab tanpa pengalaman yang demikian, tentu Maryam tidak akan berani menantang publik agar Isa berbicara di hadapan mereka. Ketiga, berdasarkan logika kehormatan Jibril. Bagaimana mungkin Jibril berbicara berada di bawah Maryam yang sedang melahirkan dalam kondisi kotor dan tentu saja juga dalam kondisi

\footnotetext{
54 Departemen Agama RI, al-Qur'ân dan Terjemahnya, 306-307.

55 'Abd al-Qâdir, Bayân al-Ma'ânî, Vol. 2 (Damaskus: al-Taraqqi, 1382 H), 148.

56 al-Râzî, Mafâtîh al-Ghayb, Vol.21, 527.

${ }^{57}$ al-Qurțuî, al-Jâmi' li Aḅkâm al-Qur'ân, Vol. 11, 93.
} 
auratnya terbuka. Situasi dan kondisi yang demikian tentu akan mencederai citra Jibril sebagai sosok suci. ${ }^{58}$

Pembicaraan yang disampaikan Isa tersebut berupa empat hal: Pertama, "Janganlah kamu bersedih hati, sesungguhnya Tuhanmu telah menjadikan anak sungai di bawahmu". Kisah ini diceritakan dalam Q.S. Maryam [19]: 24. Kedua, "Dan goyanglah pangkal pohon kurma itu ke arahmu, niscaya pohon itu akan menggugurkan buah kurma yang masak kepadamu". Kisah ini diceritakan dalam Q.S. Maryam [19]: 25. Ketiga, "Maka makan, minum dan bersenang hatilah kamu". Kisah ini dikemukakan dalam Q.S. Maryam [19]: 26. Keempat, "Jika kamu melihat seorang manusia, maka katakanlah: "Sesungguhnya aku telah bernazar berpuasa untuk Tuhan Yang Maha Pemurah, maka aku tidak akan berbicara dengan seorang manusia pada hari ini". Kisah ini merupakan kelanjutan dari perkataan Isa kepada Maryam yang terdapat dalam Q.S. Maryam [19]: 26.

Adapun jika kisah yang terdapat dalam Q.S. Maryam [19]: 24-25 ini dibaca dengan teori tindak tutur, maka lokusinya menunjukkan bentuk kalimat larangan dan perintah. Kalimat lâ taḩ̧anı̂ merupakan larangan kepada Maryam agar tidak boleh bersedih dengan kondisi dan situasi kelahiran yang sedang dialaminya. Sedangkan kalimat yang menunjukkan perintah yaitu terdapat pada kalimat, wa buгzî́, fa kuli wa ishrabî wa qarrî̀ 'aynan dan kalimat fa qûlî. Kalimat tersebut merupakan perintah Isa kepada Maryam agar beliau menggoyangkan pohon kurma, makan dan minum serta perintah untuk bersikap diam.

Berbeda dengan teori lokusi yang menunjukkan kalimat perintah dan larangan, illokusi ayat tersebut berupa kalimat direktif (direktives) yang berbentuk memohon (requesting). Permohonan tersebut disampaikan Isa dalam rangka untuk memberikan ketenangan pada diri Maryam dari rasa kesepian yang mencekam dirinya ${ }^{59}$ sebab telah disediakan fasilitas makanan dan minuman. Karena itu, pada ayat berikutnya, Q.S. Maryam [19]: 25, Isa memohon kepada Maryam agar memanfaatkan fasilitas tersebut dengan cara menggoyangkan pohon kurma kering kering, tidak berdahan, tidak berbuah dan tidak pula berkuncup yang ada di padang sahara Bayt al-Maqdis. ${ }^{60}$

\footnotetext{
58 al-Khatîib, al-Tafsîr al-Qur'ânî li al-Qur'ân, Vol. 8, 732. Bandingkan dengan: al-Râzî, Mafâtîh al-Ghayb, Vol. 21, 527. Lihat juga al-Ṭabarî, Jâmi al-Bayân, Vol. 15, 505. Lihat juga al-Andalûsî, Tafsîr al-Baḥr al-Muhît, Vol. 7, 253.

${ }^{59}$ al-Qushayrî, Latâ if al-Ishârât, Vol. 2 (Mesir: al-Hay'ah al-Misrîyah, t.th.), 425.

60 al-Qurtubî, al-Jâmi‘ li Aḅkâm al-Qur'ân, Vol. 11, 92. Lihat juga Abû al-Qâsim Muḥmûd b. 'Umar b. Aḥmad al-Zamakhsharî Jâr Allah, al-Kashshâf 'an Haqâaiq al-
} 
Sedangkan implikatur yang terdapat dalam Q.S. Maryam [19]: 24 menunjukkan bahwa Maryam adalah sosok ibu sejati yang mempunyai hubungan emosional dengan banyinya. Karena itu wajar jika dalam konteks ayat ini, Isa memohon agar Maryam tidak bersedih hati. Sedangkan implikatur perintah menggoyangkan pohon kurma kering kepada Maryam yang terdapat dalam Q.S. Maryam [19]: 25, selain merepresentasikan tanggung jawab seorang ibu yang harus bekerja keras, ${ }^{61}$ juga yang sangat signifikan dalam unsur feminisme adalah tanggung jawab seorang ibu dalam memberikan rasa aman dan nyaman buat bayinya, sehingga tidak mati kelaparan akibat gizi buruk yang dideritanya.

\section{Penutup}

Konstruksi pragmatika al-Qur'ân adalah suatu disiplin ilmu yang mengkaji al-Qur'ân dari sudut pandang relasi antara konteks linguistik yang bersifat diadik dan konteks non-linguistik yang bersifat triadik. Adapun bentuk feminisme kisah Maryam perspektif tindak tutur dan implikatur dalam pragmatika al-Qur'ân itu meliputi akses menyuarakan kekecewaan dan perlawanan terhadap tradisi misoginis yang terdapat dalam Q.S. Âli 'Imrân [03]: 36, akses mendapat hak edukatif yang terdapat dalam Q.S. Âli 'Imrân [03]: 37, akses melaksanakan ajaran spritualitas di wilayah publik dalam Q.S. Âli 'Imrân [03]: 43, akses melakukan bentuk perlawanan terhadap praktik pelecehan seksual dalam Q.S. Maryam [19]: 18 dan juga tanggung jawab seorang ibu dalam memberikan rasa aman dan nyaman buat bayinya, sehingga tidak mati kelaparan akibat gizi buruk yang dideritanya.

\section{Daftar Rujukan}

'Itr, Nur al-Dîn. 'Ulûm al-Qur'ân al-Karîm (Damaskus: Matba'at alSabah, $1414 \mathrm{H}$.

Aḥmad, Yûsuf al-Hầj. Mawsû́at al-Ijầz al-Tlmî. Damaskus: Maktabah Dâr Ibn Hajar, 1424.

Ainin, Moh. Fenomena Pragmatika dalam al-Qur'an. Malang: Misykat, 2010.

Andalûsî (al), Abû Ḥayyân. Tafsîr al-Baḥr al-Muhît, Vol. 2 (Beirut: Dâr al-Fikr, $1420 \mathrm{H}$.

Tañ̂̀l wa 'Uyûn al-Aqâwîl fì Wujub al-Ta'wîl, Vol. 3 (Beirut: Dâr al-Kitâb al-'Arabî), 11. Lihat juga al-Baghawî, Ma'álim al-Tanzîl, Vol. 5, 225.

${ }^{61}$ al-Qurțubî, al-Jâmi' li Aḅkâm al-Qứân, Vol. 11, 94-96. 
Baghawî (al), Muhammad Husayn. Ma álim al-Tanæîl, Vol. 2 (Beirut: Dar Tayyibah, $1417 \mathrm{H}$.

Chaer, Abdul. Sosiolinguistik: Perkenalan Awal (Jakarta: Rineka Cipta, 2004.

Cummings, Louis. Pragmatik: Sebuah Perspektif Multidisipliner, terj. Eti Setiawati. Yogyakarta: Pustaka Pelajar, 2007.

Dhahabî (al), Muhammad Ḥusayn. al-Tafsîr wa al-Mufassirûn (t.tp.: tp., $1396 \mathrm{H}$.

Fathurrosyid. "Eksistensi al-Qur'ân: Kajian Ontologi, Epistemologi, dan Aksiologi", Studi al-Qur'ân. Surabaya: Kopertais IV Press, 2015.

----. Semiotika Kisah al-Qur'ân: Membedah Perjalanan Religi Raja Sulaiman dan Ratu Balqis. Surabaya: Pustaka Radja, 2015.

Gazdar, Gerald. Pragmatic Implicature: Presupposition and Logical Form. New York: Academic Press, 1979.

Ghazali, Abd Muqsith. Metodologi Studi al-Qur'an. Jakarta: Gramedia Pustaka Agama, 2009.

Goldziher, Ignaz. Madhâhib al-Tafsîr al-Islâmî (Beirut: Dâr Iqra', 1403).

Rûmî (al), Fahd 'Abd al-Rahmân b. Sulaymân. Ittijâhât al-Tafsîr fî̀ al-Qarn 'Asrr. Riyad: Mu'asasat al-Risâlah, 1418.

Griffiths, Patrick. an Introduction to English Semantics and Pragmatics. Edinburgh: Edinburgh Universtiy Press, 2006.

Gunarwan, Asim. Pragmatik: Pandangan Mata Burung. Jakarta: Unika Atmajaya, 1993.

Hararî (al), al-'Alwî. Tafsî̀ Hadâ'iq al-Rûh wa al-Rayḥ̂an fì Rawâbî Ulûm al-Qur'ân, Vol. 17. Beirut: Dâr Tûq al-Najâh, 1421.

Ibrâhîm (al), Mûsâ Ibrâhîm. Bubûth Manhajîyah fì 'Ulûm al-Qư'ân alKarîm. Amman: Dâr 'Ammar, 1996.

Jâr Allah, Abû al-Qâsim Muḥmûd b. 'Umar b. Aḥmad alZamakhsharî. al-Kashshâf 'an Haqâiq al-Taņ̃îl wa 'Uyûn al-Aqâwîl fî̀ Wujub al-Ta'wr̂l, Vol. 3. Beirut: Dâr al-Kitâb al-'Arabî.

Jawzî (al), Ibn. Zâd al-Masîr fî̀ 'Ilm al-Tafsîr, Vol. 8. Beirut: Dâr al-Fikr, 1407.

Jurjânî (al), 'Abd al-Qâhir. Darj al-Darar fî̀ Tafsîr al-Âyi wa al-Suwar, Vol. 2. Amman: Dâr al-Fikr, 1430.

Khalîfah, Akram. Jam' al-Qur'ân: Dirâsah Taḅlilîyah li Marwiyyatih. Beirut: Dâr al-Kutub, 1427.

Khalwatî (al), al-Hanafî. Tafsîr Rûh al-Bayân, Vol. 5. Beirut: Dâr Ihyyâ', t.th. 
Khân, Ṣâdiq. Fatḥ al-Bayân fî̀ Maqâsìid al-Qur'ân, Vol. 2 (Beirut: alMaktabah al-'Așrîyah, $1412 \mathrm{H}$.

Khațîb (al), 'Abd al-Karîm. al-Tafsîr al-Qur'ânî li al-Qur'ân, Vol. 2. Kairo: Dâr al-Fikr al-'Arabî, t.th.

Kreidler, Charles W. Introducing English Semantic. London: Routledge, 1998.

Kuntowijoyo. Islam sebagai Ilmu Epistemologi, Metodologi, dan Etika. Jakarta: Teraju, 2004.

Levinson, Stephen C. Pragmatics. Cambridge: Cambridge University Press, 1992.

Mey, Jacob L. Pragmatics: an Introduction. Hongkong: Blackwell Publishing, 2001.

'Âshûr, Muhammad al-Tâhir b. Tafsîr al-Taḥ̂î wa al-Tanwîr, Vol. 15. Beirut: Mu'asasah al-Tarikh al-'Arabi, 2000.

Nababan, PWJ. Ilmu Pragmatik: Teori dan Penerapannya. Jakarta: Departemen Pendidikan dan Kebudayaan, 1987.

Nabhân (al), Muhammad Fârûq. al-Madkhal lî al-Tashrî al-Islâmî. Beirut: Dâr al-Qalam, 1981.

Purwo, Bambang Kaswati. Deiksis dalam Bahasa Indonesia. Jakarta: PN Balai Pustaka, 1984.

-----. Pragmatik dan Pengajaran Bahasa: Menyibak Kurikulum 1984. Yogyakarta: Kanisius, 1990.

Qâdir (al), 'Abd. Bayân al-Ma'ânî, Vol. 2. Damaskus: al-Taraqqi, 1382 H.

Muḥammad Jamâl al-Dîn b. Muḥammad Saî̀d b. Qâsim al-Ḥallâq alQâsimî, Mahâasin at-Ta'mîl, Vol. 4 (Beirut: Dâr al-Kutub al-'Ilmîyah, $1418 \mathrm{H}), 133$.

Qinnûjî̀ (al), Luṭ̂ Allâh. Fatḥ al-Bayân fî̀ Maqâsìi al-Qur'ân, Vol. 2. Beirut: al-Maktabah al-'Așrîyah, 1412.

Qurțubî (al), Muḥammad b. Aḥmad al-Anșârî. al-Jâmi' li Aḥkâm alQur'ân. t.t.: Muassasat al-Risâlah, 2006.

Qushayrî (al), Latâîf al-Ishârât, Vol. 2. Mesir: al-Hay'ah al-Misrîyah, t.th.

Râzî (al), Fakhr al-Dîn. Mafâtîh al-Ghayb, Vol. 8. Beirut: Dâr al-Kutub al-'Ilmîyah, 2000.

Rustono. Pokok-pokok Pragmatik. Semarang: IKIP Semarang Press, 1999. 
Șâbûnî (al), Muhammad Alî. Șafwat al-Tafâsîr, Vol. 2. Mekkah: Dâr alSâbûnî, t.th.

Ṣâlih, 'Abd al-Qâdir Muhammad. al-Tafsîr wa al-Mufassirûn fí al-'Asr alHadith. Beirut: Dâr al-Ma'rifah, 1424 H.

Sâmirî (al), Fâdil Ṣâliḥ. Lamsât Bayânîyah li Sûrat al-Qư'ân, Vol. 1. Beirut: Dâr al-Fikr, t.th.

Sha'râwî (al), Muhammad Mutawallî, Tafsîr al-Sha'râwn̂, Vol. 1. Kairo: Akhbâr al-Yawm, 1991.

Shâhîn, 'Abd al-Ṣabûr. 'Arabiyyat al-Qur'an. t.t.: Maktabat al-Shahab, t.th.

Ṭabarî (al), Abû Ja'far. Jâmi' al-Bayân fî̀ Ta'mîl al-Qư'ân, Vol. 15. t.t.: Muassasat al-Risâlah, 2000.

Ṭabâtabâ'î (al), Muhammad Ḥusayn. al-Mî̀ân fì Tafsîr al-Qur'ân, Vol. 3. t.t. Manshûrât Muassasat al-A 'lamî li al-Maṭbûât, 1997.

Ṭanțâîi (al), Muhammad Sa îd. al-Tafsîr al-Wasît li al-Qur'ân al-Karim, Vol. 2. Kairo: Dâr Nahḍat Miṣr li al-Ṭibâ‘ah wa al-Nashr wa alTawzî̀, 1998.

Tayyâr (al), Musâ'id Sulaymân. al-Tafsîr al-Lughawî li al-Qur'ân al-Karim. Mekkah: Dâr Ibn al-Jawzî, t.th.

Tarigan, Henry Guntur. Pengajaran Pragmatik. Bandung: Angkasa, 1990.

Tha'âlabî (al), Abû Zayd. al-Jawâhir al-Hịân fî Tafsîr al-Qur'ân, Vol. 2. Beirut: Dâr Ihyầ' al-Turâth, 1418 H.

Thomas, Jenny. Meaning in Interaction: an Introduction to Pragmatics. New York: Longman, 1995.

Wardhaugh, Ronald. an Introduction to Sociolinguistics. Hongkong: Blackwell Publishing, 2006.

Yule, George. Pragmatics. Oxford: Oxford Universty Press, 2006.

Zayd, Nașr Hâmid Abû. al-Nașs, al-Sultah, al-Haqîqah: al-Fikrîyah alDinîah bayn Irâdat al-Ma'rifah wa Irâdat al-Haymanah. Beirut: alMarkaz al-Thaqâfî, 1995.

Zuhaylî (al), Ibn Mușțafâ. Tafsî̀ al-Munîr fi al-'Aqîdah wa al-Sharî‘ wa al-Manhaj, Vol. 6. Damaskus: Dâr al-Fikr al-Mu'așir, 1418. 